水文・水資源学会誌

J. Japan Soc. Hydrol. \& Water Resour.

Vol. 10, No. 4 (1997) $\quad$ pp. 329-336

\title{
銀座オフィスビル街における熱収支特性
}

\section{Field Observation of the Heat Balance in an Urban Area}

$\begin{array}{ll}\text { 神田 学* } & \text { (東京工業大学工学部) } \\ \text { Manabu KANDA } & \text { Tokyo Institute of Technology } \\ \text { 高柳百合子* } & \text { (東京工業大学工学部) } \\ \text { Yuriko TAKAYANAGI } & \text { Tokyo Institute of Technology } \\ \text { 横山 仁** } & \text { (東京都農業試験場) } \\ \text { Hitoshi YOKOYAMA } & \text { Tokyo Metropolitan Agricultural Experiment Station } \\ \text { 森脇 亮* } & \text { (東京工業大学工学部) } \\ \text { Ryo MORIWAKI } & \text { Tokyo Institute of Technology }\end{array}$

The field observations were performed in Ginza office area in summer 1996, to investigate the characteristics of heat balance in complicated urban canopies. The sensible heat was measured by two methods, one was "eddy correlation method" and another was "scintillation method". The following results were obtained ; 1) The observed latent heat flux was very large and comparable to the sensible heat flux. This was proved to be caused by cooling systems introduced to office buildings. 2) The artificial and latent heat on a holiday were less than those on a weekday. 3) The sensible heat observed by scintillation technique agreed well with that by the eddy correlation method. And also, the longer measure ment path of scintillation meter $(130 \mathrm{~m}$ in this case) compared to that of sonic anemometer (only $15 \mathrm{~cm}$ ) could make the fluctuations smaller. 4) The displacement height (d) was found to be very sensitive to the results of scintillation methods and the way how to determine it was discussed.

Key words : The artificial energy flux, The artificial latent heat flux, Cooling systems, Scintillometer

1996年 8 月に銀座オフィス街において, 都市上空の䓡収支特性に関する観測を行った。渦相関法とシンチレーション法を併用した 計測により，以下の結果を得た。1）銀座オフィス街での熱収支の実態を明らかにし，影熱・潜熱・蓄熱が同程度の割合で寄与して いることを明らかにした，2）都市は影熱に匹敵する以工的な潜熱」を出しており，原因として冷房による潜熱放出が有力な候補 であることを示した，3）建物側面の空などからの蓄熱量は無視できない大きさでり，休日の人工熱及び潜熱は平日より少なかっ た. 4) シンチレーション法によるキャノピー上端の影熱量は, 渦相関法によるビル屋上の影熱とほ怔一致し, ビル屋上での計測の 代表性が確㑇された，4）都市キャノピーにおけるシンチロメータの利用に際しては,ゼロ面変位の算定が重要であることを示し， その決定手法を提案した。

キーワード : 人工熱, 人工的な潜熱, 冷房, シンチロメータ

I 、はじめに

都市大気環境の特徴として，郊外に比べて気温が
高く相対湿度が低いことは早くから知られ，東京は 都市砂漠とも呼ばれてきた。 そのためヒートアイラ ンド現象に代表される熱環境の研究の多くは，郊外

*東京工業大学工学部 个152 東京都目黒区大岡山2-12-1

Faculty of Engineering, Tokyo Institute of Technology, Tokyo 2-12-1 Ookayama, Meguro 152

**東京都農業試験場

Tokyo Metropolitan Agricultural Experiment Station 
と対比させて, 都市の顕熱は大きく, 潜熱は小さい か, あるいは無いものと仮定される場合が殆どであ る. しかし近年, アメダス資料による東京都市域の 夏の午後の降雨量の増加(藤部, 1996)や, 空調機器な どの冷却水に伴う水蒸気量増加の可能性が定性的に 報告(小元ら，1994)されるなど, 都市の潜熱量や水蒸 気量にはまだ不明な点が見られる。また，気温上昇 の原因の 1 つとされる人工熱や建造物への蓄熱量に 関しては, 直接測定することは難しく, 信頼できる データを用いて定量的に論じた研究恃意外に少ない (例えばYoshidaら，1990/池田ら，1996)。

そこで本論文では，都市の熱収支の実体(特に潜熱 量が本当に無視しうるものなのかどうがを明らかにす る事を目的として, 実際に都心のオフィスビルの屋 上で1996年夏に測定した観測結果を検討する。顥 熱・潜熱の算定にあたっては既存の測定手法の中て 最も信頼性の高い渦相関法による結果を基本的に用 いた. しかしながら都市キャノピーのような複雑面 では点計測の代表性が大きな問題として考えられて いる.そこで, 計測スパン長が数百的にも及び(超音 波風速計などはスパン長が数 $10 \mathrm{~cm}$ に過ぎない)、広域に わたる平均的な影熱量を直接計測し得る新しい手法 として注目されているシンチロメータを利用した影 熱算定も併せて行い, その利用可能性についても検 討を試みた。

\section{II . 観測の概要}

観測は, 東京都千代田区丸の内 (図一 1 参照)の東京 都庁丸の内庁舎の屋上で, 平成 8 年 8 月 6 日から 8

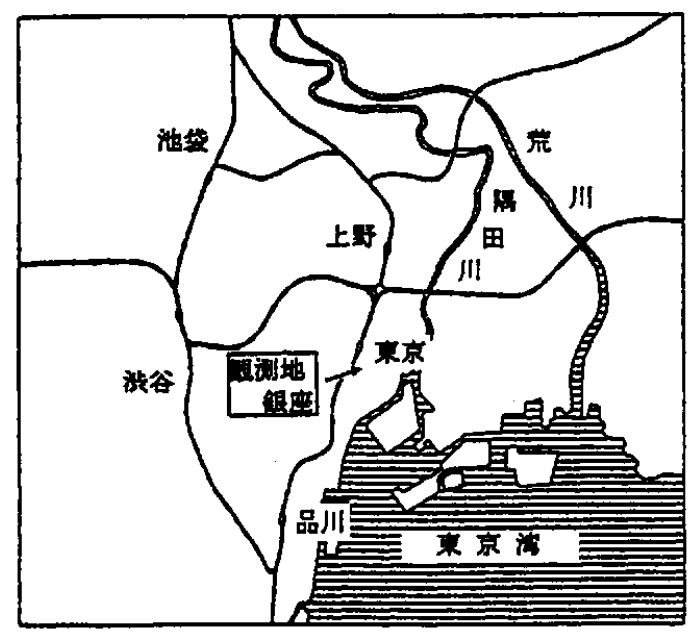

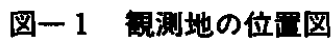

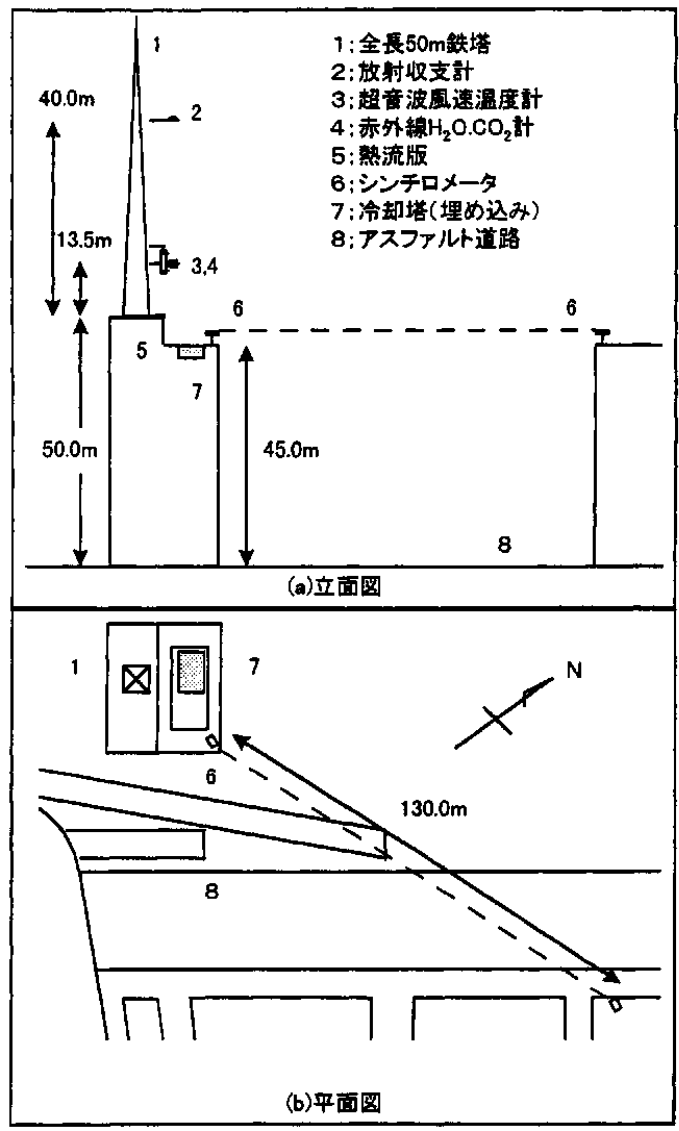

图一2 計器設置の概略図

(a) 道路と垂直に切断した立面図

(b) 上から見た平面図

月 8 日の前半 3 日間と, 8 月18日から 8 月22日まで のお盆を挟んだ後半 5 日間に行った。周辺はオフィ スや百貨店など法定容積率が $400 \%$ 以上のビルが林 立する, 都内でも特に電力需要の高い地域となって いる.

観測項目は, 放射収支計による正味放射量, 超音 波風速温度計((㧣) カイジョー, DA600型)による風 向・風速・温度データと, 熱流版による屋上面の伝 熱量の計測を基本とする。 それに加えて, 前半の 3 日間にはシンチロメータ(Sintec, SLS20)によるビル 間道路上空の顕熱計測を, また後半の 5 日間には赤 外線 $\mathrm{H}_{2} \mathrm{O} \cdot \mathrm{CO}_{2}$ 計 ((株)アドバネット, $\left.\mathrm{E} 009 \mathrm{~A}\right)$ にる 潜熱計測を併せて行った。計器はビル屋上に立って いる鉄塔に，図一2のように設置した。ビルは15階 建て, コンクリート製で扊色, 側壁は 4 面とも面積 の約 3 割程が空となっている. 


\section{III. 観測の結果と考案}

\section{1 . 都市上空の熟収支}

\section{1) 熱収支式}

ここでの熱収支は，図一３のようにキャノピー層 を含めたコントロールボリュームを設定して考える。 観測地点の風上周囲数 $\mathrm{km}$ 四方程度は，銀座の中心に 位置し，規則正しい基盤目状の区画網に50m以下の 建築物が密集しており(後述図一6参照)，グロスな視 点からビル群を立体的粗度と見なした場合, それら は水平数 $\mathrm{km}$ 程度のスケールにおいてほほ一様である と考えられる. 従って，森林熱収支などの場合と同 様, 観測ポイントは熱内部境界層内にあるものと見 なし，移流の影響は考えないことにする．海陸風フ ロントの通過時などに移流の影響が熱収支に現れる ことは著者らも別の観測で確かめているが(神田他, 1996)，それはあくまで瞬時値的なものである.

以上の仮定に基づき，図一 3 における都市キャノ ピー層内の熱収支式は次式のように表せる。

$$
R_{n}+M=H+l E+G+G^{\prime}+Q
$$

ここで, $R_{n}$; 正味放射, $M$; 人工熱, $H$ : 顥熱,

$l E$; 潜熱, $G$; 屋根面への蓄熱, $G^{\prime}$; 側面・空・道 路等への蓄熱, $Q$; 大気の蓄熱,であり，Qは十分小 さく無視できると考える，例えば，冷房駆動のため の電力消費は $M$, 冷却水への蓄熱は $G$ また $G^{\prime}$, 冷

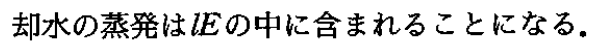

顕熱・潜熱は，超音波風速温度計で計測した温 度・風速の変動量と, 赤外線 $\mathrm{H}_{2} \mathrm{O} \cdot \mathrm{CO}_{2}$ 計で計測し た水蒸気量の変動量 (どちらも $10 \mathrm{~Hz} て ゙$ 記録)から渦相 関法により求めた值を用いる. 計測していない $M$, $G^{\prime}$ については, $R, G, H, l E$ の計測值と式(1)から， 次式により推定する.今回の観測範囲では， $M$ と $G^{\prime}$ を分離して評価する事はできない。

$$
M-G^{\prime}=(H+l E+G)-R_{n}
$$

都市キャノピーの熱収支て問題となるのが，観測 点の代表性の問題である。顕熱については, 後章で シンチロメーター計測值によりその空間代表性が議

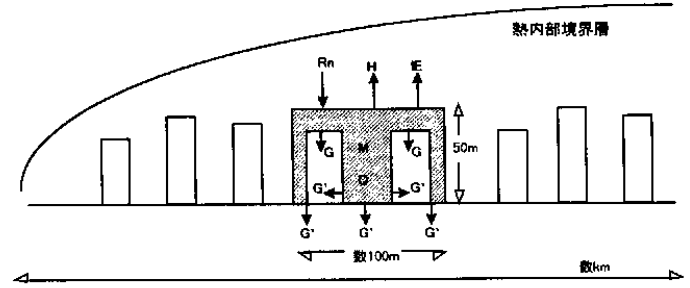

図一３慗收支の取り方の概念図
論される。純放射はキャノピー高さの約 2 倍に相当 する90m地点での点計測値であり，また地熱流は屋 上面 5 点の平均值であるが，いずれも簃密な意味で その代表性をここて議論することはてきない(多く のアパート・ホテルなどでは基本的に観測許可は扔ず， そういった観測遂行上の障害が少なからず関与してい る）ただし，著者らは，既にサーモグラフィー熱画 像から領域平均的な地面の堛熱量と純放射を道推定 する方法(サーモG)を提案し，フラットな場でその 有効性を検証して扔り(森脇・神田, 1997), 今後サー モGを都市キャノピーに適用していくことを課題と したい.

\section{2）实測㺘収支}

熱収支の結果例を，超音波風速温度計による風・ 温度のデー夕と併せて示す(图一4, 图一5)。ここて は潜熱計測を行った後半 5 日間の内, 平日と休日の 代表としてそれぞれ21日(水矅日)と，18日(日曜日)の 2 日間を取り上げた。全般的傾向として，都市キャ ノピーでは，䫓熱・潜熱・蓄熱の 3 項が定量的に同 程度の寄与を行っていると言える．以下に詳しく考 察する.

(a)
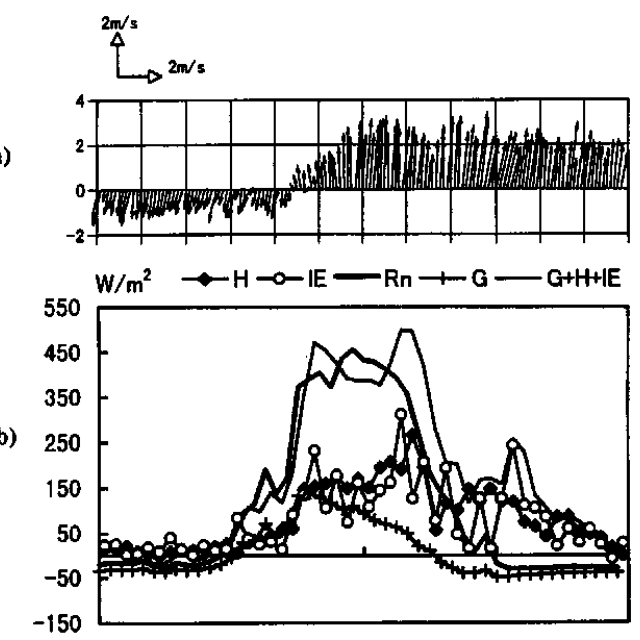

(c)

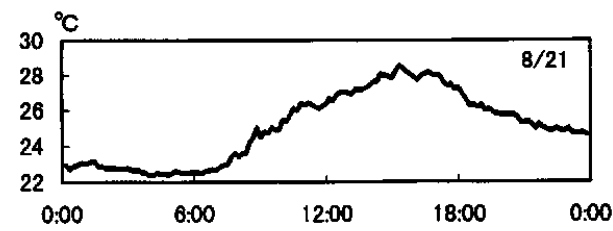

图一48月21日(水曜日)の時系列データ

(a) 風向. 風速の時間変化 (10分平均)

(b) 熱収支の時間変化 (30分平均)

(c) 温度の時間変化 (10分平均) 
(a)
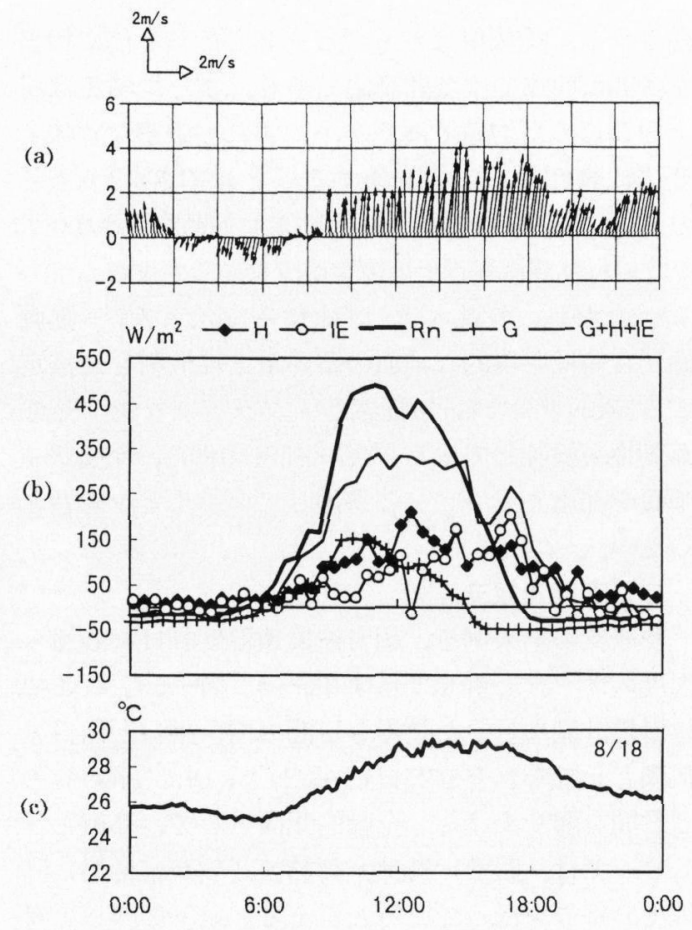

図一 58 月18日(日曜日)の時系列データ (a), (b), (c) 図-4 に同じ.

\section{(a) IEについて}

注目すべきことに，今までほとんど無いと仮定さ れてきたのに反してlEはHにほぼ等しい, 時には上 回る值を示した。両日とも日中海風による南風が 3 〜 $4 \mathrm{~m} / \mathrm{s}$ で吹いており, 図一 2 の(b)平面図を見ると 観測を行ったビル屋上の冷却塔は観測鉄塔の風下に なるため，ローカルな影響によるものでは無かろう。 またこのような現象は風向に関係なく観測期間 5 日間のデータ全てに共通して見られたことなどから も，都市では人工排熱と並ぶ『人工的な潜熱』が引 き起こされていることが考えられる。

人工熱源として扱われる自動車が，排ガスに含ま れる水蒸気によって人工の潜熱源にもなっていると いうことも考えられるので試算してみた。

$$
\begin{aligned}
C_{n} H_{m} & +(n+m / 4) \mathrm{O}_{2} \\
& \rightarrow n \mathrm{CO}_{2}+m / 2 \mathrm{H}_{2} \mathrm{O}+H_{u}
\end{aligned}
$$

ここで,Hu：ガソリンの燃燒熱 $(10,430 \mathrm{kcal} / \mathrm{kg})$ $n=8, m=15.5$ (定数)を表す.

化学式(3)から求めると, 潜熱は自動車の全燃焼熱 のおよそ7\%である. 例えば，国道246号線に拈ける 激しい渋滞時に, 通過交通による燃焼熱 (人工排熱) は200〜 $300 \mathrm{~W} / \mathrm{m}^{2}$ 程度に及ぶことが実測により示さ
れているが(神田他，1997)，そのような場合を想定し

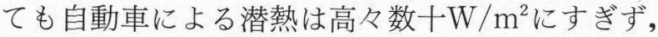
数百 $\mathrm{W} / \mathrm{m}^{2}$ の潜熱量を説明することはできない.

そこでその他の原因として，冷房を検討してみた。 大型ビル用の冷房は普通住宅用の冷房とは異なり, ビル内の熱を最終的に屋上の冷却塔で蒸発による潜 熱の形で消費する冷水の循環方式を採用している. 冷却塔とは，噴霧器によって水と空気の接触面積を 大きくし，かつ充填材に染み込んでいく水滴に下か ら空気を送りこむことによって，効率よく強制的に 蒸発を促進するものである，密閉生の高いビル内に おいては夏期の冷房は不可欠で，観測を行ったビル の屋上には合計で 5 つの冷却塔が設置して有り，合 計で毎分 18,054 リッルもの冷却水が循環していた。 観測地周辺にはこのビルのように個別に冷却塔を設 置するものの他に，地域冷暖房に加入しているビル も多い. 地域冷暖房とは, 指定地域内の一つのプラ ントに冷暖房用の熱源機器を集約し冷却塔等を設置 し，他の加入ビルには熱媒体のみを配管供給するも のである。地域冷暖房は東京都の都市計画として進 められいるためデータが整っており，提供して頂い た 8 月の 1 ケ月間の冷房用使用水量 $(=$ 入れ替え水及 び機械損失などを差し引いた使用水量で，ほぼ蒸発によ る損失に対応すると思われる) と地域内のべ床面積か ら，算定した指定地域内の潜熱量を示す。この両日 とも日中は海風により南風が卓越しており,データ は風上の影響を受けていると考えられるため，観測 地点のすぐ南側の 2 つの地域冷暖房指定地域をとり あげた。図ー6に観測地との位置関係を示す.

銀座二・三丁目地区 $\cdots \cdots \cdots \cdot \cdots \cdot 175.3 \mathrm{~W} / \mathrm{m}^{2}$ (平成 7 年) 銀座四丁目 $372.4 \mathrm{~W} / \mathrm{m}^{2}$ (平成 8 年) これは夜間を含めた平均值なので昼間のピーク時

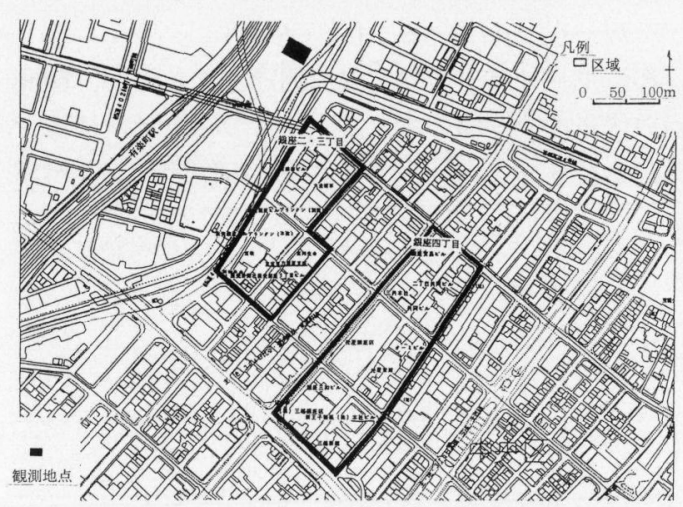

図一 6 観測地周辺の地図 
の值はこの倍に近い值になりうるが，指定地域はビ ル街区を単位とし道路部分などを含まないため, 都

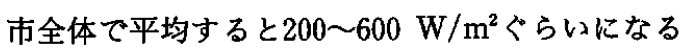
と推定される。この值は21日，18日のピーク時の潜 熱量200〜 $300 \mathrm{~W} / \mathrm{m}^{2}$ と比較しても妥当な範囲にあ る. 以上より, 冷却塔からの水蒸気は, 都市におけ る潜熱源として有力な候補であると考えられる。

(b) $M$ とGについて

平日の熱収支を21日（水曜日）を例にとって説明す

る. (图一 4) $G か ゙ R n$ に占める割合が大きく午前中に

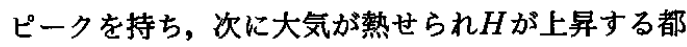
市の特徵的な日変化のパターンが見られる．Gは日 が差し始めると共に増加し, 10 時頃に $130 \mathrm{~W} / \mathrm{m}^{2}$ を示 した後は単調に減少する. その後 $H$ は14時頃まで増 加し，16時頃に気温が最高となる一方でGが負に転 じている，気温は日没後もなかなか下がらず，日中 建物に蓄熱されたエネルギーが主に長波放射によっ て放熱され，ヒートアイランド現象が起きていると 考えられる.

顕熱だけでなく潜熱も前述の冷房の矨果によって 気温の上昇と共に増加しているが，9時から10時頃 に風向の変わり目で風速が小さくなっている時に, 計器を設置したビル鉄塔の足下にある冷却塔の局所 的な影響を受け，小さなピークをもっている。それ とGのピークが重なり, $H+l E+G$ は午前と午後に 2 つのピークを持つ形になっている.

グラフ中の $H+l E+G$ と $R_{n}$ の差は, 式(2)より $M$ とGの差として捉えることができ，正午付近を除い て $M>G^{\prime}$ であり, 人工熱が $G^{\prime}$ を回る量を出してい ることがわかる. 夕方以降に $R_{n}$ との差が大きく開く のは，Mが増大していると言うょりも，G'保負に転 じることによるものであると推察される. 正午付近 で $M<G^{\prime} に$ 逆転しているのは, 日射の差込によるビ ル側面の空から建物への蓄熱, あるいは建物のコン クリートに比べて日射に鋭敏に反応するアスファル 卜道路への蓄熱量が増大する事 $(\mathrm{Vu}$ Thanh $\mathrm{Ca}$ ら, 1994）に対応していると思われる. 晴天日の日中にビ

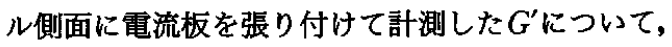
Gの1.5倍を示すという報告(Yoshidaら，1990)も合 わせ考えると，G'㒇視できない大きさであり，建 物への蓄熱量をGのみで代表することは危険である ことを示唆している.

ここで図一 5 に示す18日(日曜日)と比較すると， 曜日による人間活動の差異から人工熱に違いがでて いるのがわかる．18日は21日に比へて影熱は全体的
にやや小さめで，潜熱は明らかに小さくなっている。 冷房冷却水は休日も休まず冷水を循環し続けている が，人間活動による負荷がかからない休日は, 冷水 の温度変化が少ないため排出される潜熱量は隇少す る.そのため潜熱に平日のような日変化は見られな い. 両日は日射や風などの気象条件は類似している

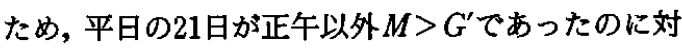

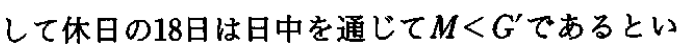
う違いは，これら顕熱・潜熱の減少によって生じて いると考えられる。これは人間活動による人工排熱 $M$ が休日は少なく平日に多いという予測を衰付け る結果である。

\section{2. シンチロメーターの利用可能性にっいて}

一般に超音波風速温度計のスパン長は, 数 $10 \mathrm{cmk}$ すぎないので，その計測值より算定される渦相関法 による顕熱は, 10 数 $\mathrm{cm}$ 四方の空間平均値と言うこと になり，複雑な都市大気の熱収支を論じる上で，そ の空間代表性が問題となる.

シンチロメーターはレーザー光の播らぎにより広 域の空間平均的な顥熱を算定しうる新しい計測技術

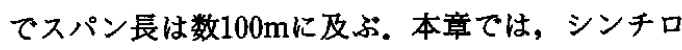
メーター法と渦相関法による顕熱算定結果を比較す ることにより, 点計測の空間代表性を検証すると同 時に, シンチロメーターの利用可能性と問題点につ いて論じる.

\section{1) シンチロメータの原理}

シンチロメータはレーザー光を用いた乱流計測計 で, 超音波計等の 1 地点での計測とは異なり,レー ザーの発信器・受信器間の光線の軌跡で空間平均化 された乱流変動值を求める点が大きな特徴である. その原理を以下に簡単に述べる. 発信される平行し た 2 本のレーザーが, 光路中の乱流により風折率の 変動を起こすのを光の強度変動としてとらえ, その 2 本の相関および光路距離などからまず, 温度の構 造関数 : $C_{T}$ とエネルギー消散率： $\varepsilon$ を求める.ここ で, 接地境界居の相似理論が適用できると仮定する と, $C_{T}$ とをは, モーニン・オブコフの相似則による 3

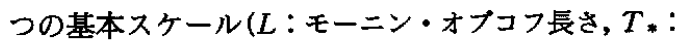
摩撩温度, $u_{*}$ : 摩擦速度) と以下の式(4)〜 (6)の関係を 有する(我々の観測では, 大気は常時不安定状態にあっ たので、ここでは不安定条件の式のみを示す). 実質的な 測定高度 $(z-d)$ が与えられれば以下の 3 式より 3 つの基本スケールが求まり, 影熱, 運動量フラック スなどが算定される。 


$$
\begin{aligned}
L= & T u_{*}{ }^{2} / k g T_{*} \\
& C_{T}{ }^{2}[k(z-d)]^{2 / 3} T_{*}^{-2} \\
= & 4 \beta_{1}\left(1-7 \frac{z-d}{L}+75\left(\frac{z-d}{L}\right)^{2}\right)^{-1 / 3}
\end{aligned}
$$

ここで,

$$
\varepsilon k(z-d) u^{-3}=\left(1-3 \frac{z-d}{L}\right)^{-1}-\frac{z-d}{L}
$$

$T$ : 設定温度, $z$ : 地上高, $d:$ ゼ口面変位

$k$ : カルマン定数 $0.4, g$ : 重力加速度 $9.81 \mathrm{~m} / \mathrm{s}^{2}, \beta_{1}$ : Obukhov-Corrsin定数0.86である.

平地における試験実験で, シンチレーション法は 渦相関法と比較してその有効性が確かめられている だけでなく，領域平均値を算出しているため渦相関 に此べ時間変動の少ないきわめて安定した結果が得 られることが指摘されている.測定原理の詳細など についは(Thiermann, 1992)を参照されたい.

従って, 点計測の代表性が大きな問題となる都市 や植物キャノピー，混在土地利用地域などからの平 均的な顕熱の算定に利用することが期待されるが, それらに応用した報告例は今のところなく，これが 初めての試みとなる(Thiermann，私信).

\section{2 ）渦相阙法との比較}

シンチロメータをキャノピー上端に設置した 3 日 間の内, 天気が悪かった 8 日を除く 2 日間の測定結 果を, 超音波風速温度計による風・温度のデータと 併せて示す(图一7，图一8). 気象条件は，6 日は晴 れ，7日は量りで午後から夕方にかけて雨模様で あった．6日の12時過ぎ頃から海風による南風が吹 いた以外は, 全体的に東海上の高気圧の影響で北北 東風が卓越している. 当初, 風向によって, 建物粗 度の異方性からキャノピー上端の境界形成の度合い に違いが出る，あるいはレーザー光路の軌跡との方 向性から光路平均値に違いが出る事などが予想され たが，意外にも風向に対応した明確な違いは見られ ない. 高さや場所の違いがあるにも関わらず，渦相 関法とシンチレーション法による影熱量は全体的な トレンドやレベルが非常に良く一致していると言え る.ただし，細かい時間変動を比較すると，洞相関 法の方がより大きな変動を示している。これは渦相 関法が高々 $15 \mathrm{~cm}$ スパンの空間平均値であるのに対し， シンチロメータは約130mスパン(約100倍)の空間平 均値となっていることの影響が現れたものと考えら れる。

1 節では屋上での計測を基にキャノピーを含めた 都市大気の熱収支を議論したが，屋上 1 箇所のみの (a)

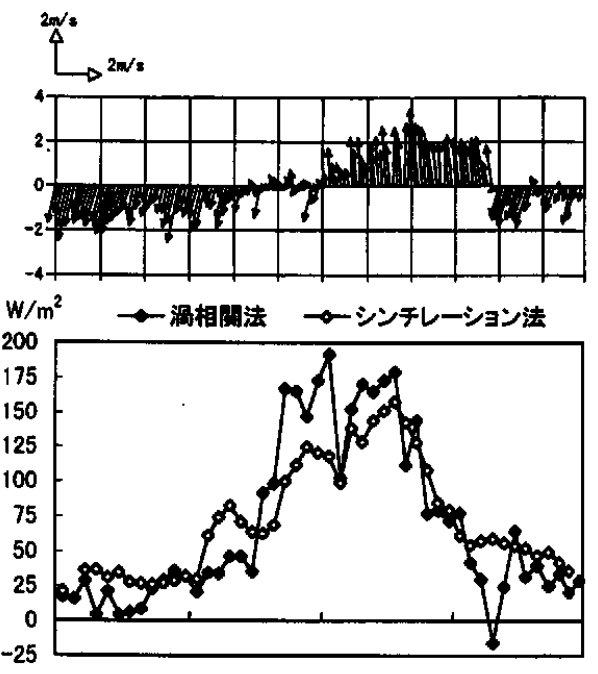

(c)

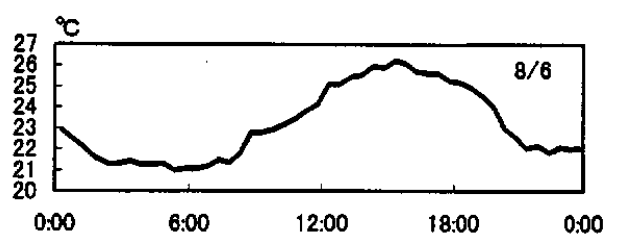

图ー7 8月 6 日の時系列データ

(a) 風向. 風速の時間変化 ( 30 分平均)

(b) 渦相関法, シンチレーション法による顥熱 の時間変化 (30分平均)

(c) 温度の時間変化 (110分平均)

(a)

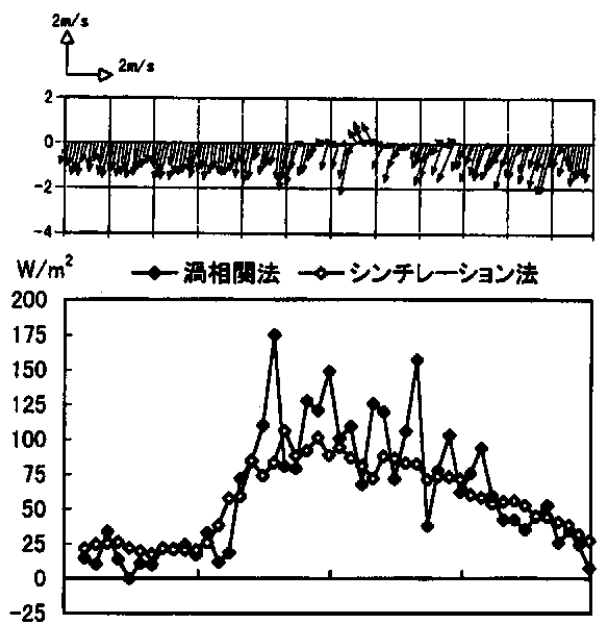

(c)

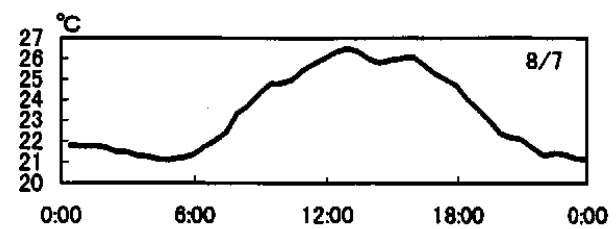

图一8 8月7日の時系列データ (a), (b), (c) 図一 7 R同じ. 
点計測值がどれだけの代表性を持つかは定かではな かった。ここでシンチロメータによる領域平均的な 線計測値と比較することによって，顕熱に関しては 一応の代表性を確認することができたといえる。

\section{3 ) 高さの周題}

シンチレーション法は1)項で示したように,レー ザー光の実質的な地上高 $(z-d)$ の情報を必要とす る. 平地とは異なる我々の観測のような場合には， ビルの影響を考慮したゼ口面変位 $d$ をあらかじめ与 えなければならず，これをいかにして決めるかとい うこと自体が大きな問題点となる. 2 ) 項での解析で は東京などのようにビルが密に詰まっている場合に

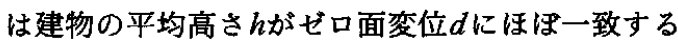
(Kondoら, 1986)こと, 及びシンチロメーターの設置 高度がビルの屋上面から $5 \mathrm{~m}$ であることを考慮して， $z-d=5 \mathrm{~m}$ としていた.ここで $d$ が顕熱の算定にど の程度影響するか感度分析を行ってみた．建物高さ $50 \mathrm{~m}$ 1 割程度以内で $d$ をわずかに変化させて再計 算させたところ，高さの增隇は無視できない割合て 顯熱の算定に効いていることがわかった(图一9). 従って, 別途, $d$ を何らかの方法で決定させてやるこ とが不可欠となる。ここでは 2 つのアイディアを提 案してみよう。

(a) シンチロメータを 2 セッ用いる方法

同じパス間に接地高度を変えた 2 セットのシンチ ロメーター計測を行う，接地境界層内の基本スケー ルは 2 高度で変わらないから，2セットのシンチロ メー夕の出力信号から式(4) (6)内の $d$ を末知変数と して, 直接求めることが原理的には可能である.こ の手法の有効性については今後の課題としたい.

（b）超音波風速計を併用する方法 上記と同じ原理で，もう1セットのシンチロメータ

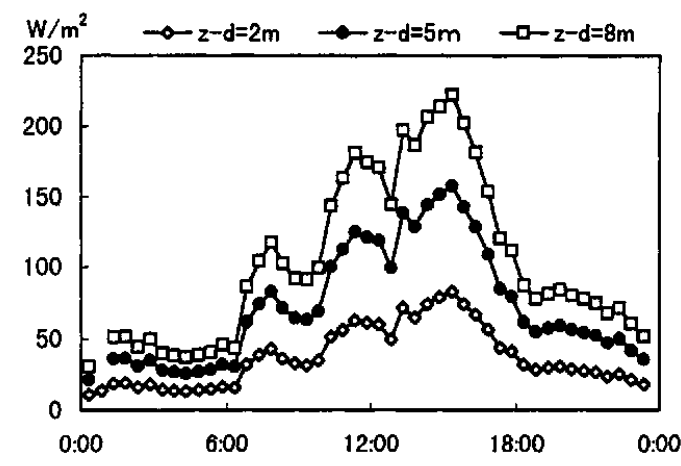

目一 9 高さzーdを $2 \mathrm{~m}, 5 \mathrm{~m}, 8 \mathrm{~m}$ 変化させた顆 熱の時闖変化
の代わりに，超音波風速計を使う手法である。

1)項の原理で説明した式(5)に,シンチロメータによ る温度の構造関数 $C_{T}$ と併せて超音波風速温度計に よる $L ， T$ を代入する事によって 一 $d$ を求めること ができる．この手法を今回の観湘結果に適用してみ た. その結果, 大気安定度の変化が小さい日中10時 $\sim 14$ 時の平均て 6 日: $z-d=5.17 \mathrm{~m}$ (標準偏差 $\alpha=$ $2.03), 7$ 日: $5.96 \mathrm{~m}(\alpha=2.73)$ を示し，2)項で採用し た屋上面を基準とする $5 \mathrm{~m}$ に非常良く一致しするこ とが示された。しかし，超音波の出力は点計測值で 有ることには変わりなく，また，標準偏差の值から もわかるように時間変動が大きいことから，本来，

(a)の方法が好ましいことは言うまでもない

以上から, 今後, 複雑な地形でのシンチロメータ 計測にあたっては，ゼロ面変位を考慮した高さの処 理が重要なポイントになると思われる.しかしなが ら, 現在のところシンチレーション法は領域平均顕 熱が算定可能な唯一の測定手法であり, また複雑な 地形上では座標の取り方が難しく, McMillenによ る座標変換によってもまだ矛盾が生じる(J.C.カイ マル，1993）という超音波風速温度計の欠点を補佐で きる可能性もあるため, 今後の発展が期待される.

\section{IV.まとめ}

1996年 8 月の観測から, 都市上空の熱収支につい て以下の諸点を結論として得た。

1 . 銀座オフィスビル街での熱収支の実体を観測よ り明らかにし, 顕熱・潜熱・蓄熱が同程度に㟢与 していることを示した。

2. 都市は顕熱に匹敵する「人工的な潜熱」を出し ており，原因として冷房による潜熱放出が有力な 候補であることを示した

3. 熱収支式から人工熱と, 建物側面や空などから の蓄熱量を算定し, 休日と平日で異なる日変化パ ターンを示した

4. 渦相関法によるビル屋上の顕熱は, シンチレー ション法によるキャノピー上端の影熱のトレンド とほほ一致し, 屋上面での計測值が持つ代表性を 確認した。

5. 複雑な都市キャノピーにおけるシンチロメー夕 計測では, ゼ口面変位の算定がポイントとなるこ とを示し，その決定手法を提案した。

\section{引用文献}

池田駿介・財津知亭・渋谷昌史 (1996)：都市キャノ 
ピーの夏期の熱構造に関する現地観測, 土木学会論 文集, 35(539), pp. 167-175.

小元敬男・觶谷 憲・嚴 香 姫(1994)：わが国の都 市の近年の湿度変化, 水水学会誌, $7(2)$, pp. 106 -113 .

藤部文昭(1996)：東京都市域にお洛水量・降水 頻度の増加傾向, 日本気象学会春季大会, 69, pp. 43.

Yoshida,A. Tominaga,K. and Watatani,S $(1990 / 91)$ : Field measurements on energy balance of an urban canyon in the summer season, Energy and Buildings, 15-16, pp. 417 -423 .

J.C.カイマル (1993)：微細気象学一大気境界着の 構造と籍測一, 技報堂出版.

神田学・西村修 - 福田忠弘 - 竹内邦良・清水源治 （1996）: 河川に沿った海風フロントの進入挙動, 水工学論文集, Vol. 40, pp. 243-248.

神田 学・鈴木 襄・森脇 亮(1997)：通過交通の 影響を含めたストリートキャニオンにおける熱収
支の実測, 土木学会論文集 (投稿中).

Kondo, J. and Yamazawa, H. (1986) : Aerodynamic roughness over an inhomogeneous ground surface, Boundary-Layer Meteor., 35, pp. 331-348.

Thiermann, V. (1992): A displaced-beam scintillometer for line-averaged measurements of surface layer turbulence, the preprint volume of Tenth Symposium on Turbulence and Diffusion,29 Sept-2 Oct 1992 , Portland, pp. 244-247.

$\mathrm{Vu}$ Thanh $\mathrm{Ca}$ ・浅枝 隆・柴原千造・藤野 殼・ 中村孝一・村上雅弘(1994)：ストリートキャニオ ン内の壁・道路の温度分布, 土木学会水工学論文 集, 38, pp. 413-419.

森脇 亮・神田 学・横山 仁(1997)：地表面温度 を用いた土壤熱物性値および地中熱流量の逆推定 法の提案, 水工学論文集, Vol. 41, pp. 10971100 .

（1997年 2 月17日受付，1997年 4 月25日受理） 